\title{
FAKTOR YANG MEMPENGARUHI REMAJA SISWA SMP NEGERI 238 JAKARTA KONSUMSI SAYUR DAN BUAH
}

\author{
Factors Influencing Vegetables and Fruit Consumption Junior High School \\ Student in Jakarta
}

\author{
Chika Meidiana Amelia ${ }^{1}$, Adhilla Fayasari ${ }^{2}$ \\ Program Studi Gizi, Fakultas Kesehatan Masyarakat, Universitas Binawan \\ Email korespondensi : fayasari@gmail.com
}

\begin{abstract}
Vegetables and fruit are generally food groups that are consumed by many people because many contain benefits. Even though, in Indonesia consumption of vegetables and fruit still less than a recommendation. The purpose of this research is to identify the factors affecting the consumption of vegetables and fruit adolescents at SMP NEGERI 238 Jakarta. This research uses design cross-sectional and sampling using system random sampling that gets 107 students class VII, VIII, and IX in January 2020. The data obtained is based on the result of the questionnaire, form SQ-FFQ and Recall 24hour. Statistic data analysis used chi-square and logistic regression test. The result of this study indicates that adolescents who consumed vegetables and fruit according to recommendations per day are $24.3 \%$. Bivariate result indicate there were significant relationship between self efficacy $(p=0.034)$, availability vegetables and fruit $(p=0.048)$, parental influence $(p=0.032)$, and there is no significant relationship between knowledge $(p=0.063)$.
\end{abstract}

Keywords: availability of vegetables and fruit, vegetables and fruit consumption, parental influence, self-efficacy

\begin{abstract}
ABSTRAK
Sayuran dan buah pada umumnya kelompok pangan yang banyak dikonsumsi oleh masyarakat karena mengandung banyak manfaat. Namun, di Indonesia konsumsi sayuran dan buah masih dibawah rekomendasi anjuran. Tujuan dari penelitian ini adalah mengidentifikasi faktor-faktor yang dapat mempengaruhi konsumsi sayur dan buah pada remaja di SMP Negeri 238. Penelitian ini menggunakan desain cross sectional dan pengambilan sampel menggunakan systematic random sampling yang mendapatkan 107 siswa kelas VII, VIII, dan IX pada bulan Januari 2020. Data penelitian yang diperoleh berdasarkan hasil kuesioner, serta pengisian form SQ-FFQ dan Recall 24hour yang diisi sendiri oleh responden. Analisis data statistik yang digunakan yaitu uji chisquare dan regresi logistik. Hasil pada penelitian ini menunjukkan bahwa remaja yang konsumsi sayur dan buah baik atau sesuai rekomendasi per hari adalah 24,3\%. Hasil bivariat menunjukkan terdapat hubungan yang signifikan antara self efficacy $(p=0,034)$, ketersediaan sayur dan buah $(p=0,048)$, dan pengaruh orang tua $(p=$ $0,032)$, serta tidak terdapat hubungan yang signifikan antara pengetahuan $(\mathrm{p}=0,063)$.
\end{abstract}

Kata kunci: ketersediaan sayur dan buah, konsumsi sayur dan buah, pengaruh orang tua, self efficacy 


\section{PENDAHULUAN}

Pada umumnya tubuh manusia tidak hanya membutuhkan kalori dan protein, tetapi juga membutuhkan berbagai macam vitamin dan mineral yang banyak terdapat dalam kandungan sayur dan buah (Aswatini \& Fitriani, 2008). Sayuran hijau maupun berwarna lainnya serta buahbuahan, selain sebagai sumber vitamin dan mineral juga sebagai sumber serat dan senyawa bioaktif yang tergolong sebagai antioksidan (Kemenkes, 2017). Buah dan sayur dikenal sebagai sumber vitamin $\mathrm{C}$, khususnya pada jambu biji, jeruk, nanas, tomat, sedangkan wortel mengandung pigmen karotenoid dikenal sebagai sumber pro-vitamin A (Pardede, 2013). Mengkonsumsi sayur dan buah dengan cukup dapat mengurangi resiko terjadinya kegemukan atau obesitas. Kegemukan atau obesitas dikaitkan menjadi penyebab tertinggi kematian di seluruh dunia daripada kekurangan berat badan. Kegemukan atau obesitas merupakan faktor risiko utama untuk penyakit tidak menular seperti: penyakit kardiovaskular (terutama penyakit jantung dan stroke) yang merupakan penyebab utama kematian pada 2012, diabetes, beberapa kanker (termasuk endometrium, payudara, ovarium, prostat, hati, kandung empedu, ginjal, dan usus besar) (WHO, 2018). Cukup dalam mengkonsumsi sayur dan buah dapat mengurangi resiko terjadinya kegemukan atau obesitas. Kandungan serat dalam sayur dan buah dapat berperan dalam mencegah konstipasi dan dapat cepat membuat kenyang. Fungsi lain dari serat yaitu berperan dalam menurunkan kadar kolesterol (Wirakusumah, 2007). Menurut AKG 2013 konsumsi serat yang dianjurkan untuk remaja berusia 10-18 tahun adalah 30-35 gram per hari.

WHO (World Health Organization) telah merekomendasikan kecukupan konsumsi sayur dan buah per hari sejumlah 400 gram atau 5 porsi (WHO, 2018). Pedoman Gizi Seimbang (PGS) menganjurkan individu untuk mengkonsumsi sayur setidaknya 3-4 porsi per hari dan konsumsi buah setidaknya 2-3 porsi per hari (Kemenkes, 2016). Berdasarkan data Riskesdas tahun 2018 sebanyak 96,8\% remaja berumur 10-14 tahun mengkonsumsi sayur dan buah $<5$ porsi per hari dalam seminggu, sedangkan data DKI Jakarta tahun 2013 menyebutkan rerata konsumsi sayur pada penduduk umur $>10$ tahun adalah 1,1 porsi/hari dan rerata konsumsi buah adalah 0,7 porsi/hari, sedangkan di wilayah Jakarta Selatan rerata konsumsi sayur hanya sebanyak 0,9 porsi/hari dan rerata konsumsi buah 0,6 porsi/hari (Lembaga Penerbitan Badan Litbangkes DKI Jakarta, 2013; Lembaga Penerbitan Badan Litbangkes, 2018). 
Faktor-faktor yang mempengaruhi kurangnya konsumsi sayur dan buah antara lain umur, jenis kelamin, dan tingkat ekonomi orang tua, pengetahuan, self efficacy, dan ketersediaan sayur dan buah (Farida 2010; Lestari 2012; Wirahmah, 2016). Menurut Wirahmah (2016) didapatkan sebanyak $68 \%$ remaja dengan pengetahuan kurang. Temuan tersebut juga didukung dengan hasil self efficacy remaja yaitu sebesar $64,3 \%$ remaja memiliki self efficacy yang negatif dan sebesar 74,6\% remaja memiliki ketersediaan sayur dan buah di rumah yang negatif terhadap konsumsi sayur dan buah.

Adapun hasil yang signifikan antara variabel pengaruh orangtua dan preferensi terhadap rata-rata konsumsi sayur dan buah $(p<0,05) \quad$ (Anggraeni 2018). Remaja dengan pengaruh orangtua baik dan preferensi baik memiliki rerata konsumsi sayur dan buah yang baik. Berdasarkan uraian diatas, maka peneliti tertarik untuk melakukan penelitian dengan judul "Faktor-faktor yang mempengaruhi konsumsi sayur dan buah pada remaja di SMP Negeri 238 Jakarta"

\section{METODE}

Penelitian ini menggunakan desain cross sectional yaitu penelitian dengan metode pengumpulan data antara faktorfaktor risiko dengan efek yang dilakukan pada waktu yang bersamaan (Notoatmojo, 2010) yang dilakukan di SMP Negeri 238 Jakarta pada bulan Januari 2020. Sasaran penelitian ini adalah seluruh siswa/i SMP Negeri 238 Jakarta kelas VII. VIII, dan IX. Subyek diambil dengan teknik systematic random sampling berdasarkan total seluruh kelas yang terbagi sebanyak 18 kelompok kelas dengan sampel yang diambil sebanyak 3 kelas yang menjadi perwakilan kelas VII, VIII, dan IX dengan total sampel sebanyak 107 responden. Penelitian ini telah mendapatkan ijin dari Komisi Etik Penelitian Kesehatan Universitas Pembangunan Nasional "Veteran" Jakarta (UPNVJ), dengan nomor B/2227/XII/2019/KEPK.

Data yang diambil antara lain karakteristik, tingkat pengetahuan, self efficacy, ketersediaan sayur dan buah, dan pengaruh orangtua, serta konsumsi sayur dan buah. Data karakteristik diukur dengan menggunakan kuesioner berupa umur, jenis kelamin, tingkat ekonomi orang tua, dan status gizi.

Status gizi dikonversi dari formulasi berat badan dan tinggi badan. Pengukuran berat badan menggunakan timbangan merk GEA dengan kapasitas berat $120 \mathrm{Kg}$ dan ketelitian $0,1 \quad \mathrm{Kg}$, sedangkan untuk pengukuran tinggi badan menggunakan microtoise merk GEA dengan kapasitas skala 2 meter dan ketelitian $0,1 \mathrm{~cm}$ yang 
diukur oleh D3 gizi. Hasil formulasi status gizi kemudian dikategorikan menggunakan z-score sesuai dengan standar WHO 2005.

Konsumsi sayur buah diukur dengan menggunakan SQ-FFQ (SemiQuantitative Questionnaire) yang berisi 30 item sayur dan buah, yang didapatkan dari modifikasi penelitian Farisa (2012). Konsumsi sayur dan buah dikategorikan baik jika hasil konsumsi responden $\geq 400$ gram per hari (WHO, 2018). Selain itu, data konsumsi didukung dengan form recall 24 hour yang diisi dengan cara wawancara dengan responden,

Data mengenai tingkat pengetahuan, self efficacy, ketersediaan sayur dan buah, dan pengaruh orangtua diambil menggunakan kuesioner. Hasil uji validitas dan reliabilitas dalam penelitian ini dilakukan pada 100 remaja SMP. Setelah melakukan uji validitas didapatkan hasil bahwa dari 31 soal kuesioner, semua soal kuesioner valid dengan nilai rata-rata $r$ hitung 1,956 sedangkan uji reliabilitas didapatkan hasil dengan nilai alpha cronbach sebesar 0,617 yang dapat diartikan bahwa kuesioner yang digunakan cukup reliabel.

Kuesioner tingkat pengetahuan, self efficacy, ketersediaan sayur dan buah, dan pengaruh orang tua didapatkan dari modifikasi penelitian Anggraeni (2018). Kuesioner tingkat pengetahuan terdiri dari
15 soal yang dikelompokkan menjadi 2 kategori, jika jawaban benar mendapatkan skor 1, sehingga total skor 15. Disebut pengetahuan kurang jika jumlah skor $<60 \%$ dan baik jika jumlah skor $\geq 60 \%$ (Arikunto, 2006). Kuesioner self efficacy, ketersediaan sayur dan buah, dan pengaruh orang tua terdiri dari 6 pertanyaan dengan diberikan 4 pilihan jawaban untuk setiap pertanyaan. Variabel self efficacy dikelompokkan menjadi 2 kategori yaitu baik dan kurang dengan total skor maksimal adalah 24 . Variabel ketersediaan sayur dan buah dikelompokkan menjadi 2 kategori yaitu baik dan kurang dengan total skor maksimal adalah 16 , pertanyaan nomor 5-6 tidak dihitung dikarenakan bertujuan untuk mengetahui akses responden terhadap sayur dan buah. Variabel pengaruh orang tua dikelompokkan menjadi 2 kategori yaitu baik dan kurang dengan total skor maksimal adalah 24. Disebut self efficacy, ketersediaan sayur dan buah, dan pengaruh orang tua baik jika jumlah skor $\geq$ mean dan disebut self efficacy kurang jika jumlah skor < mean (Anggraeni, 2018).

Analisis data meliputi analisis univariat, bivariat dan multivariat. Gambaran distribusi frekuensi variabel diperoleh berdasarkan hasil analisis univariat. Untuk perbedaan rata-rata antara variabel dependen dengan variabel independen diperoleh berdasarkan analisis 
bivariat dengan batas kepercayaan yang digunakan adalah $p$-value $=0,05$ yang di uji dengan program statistika menggunakan uji chi-square. Sedangkan untuk mengetahui variabel independen yang paling besar mempengaruhi variabel dependen menggunakan analisis multivariat yang dilakukan dengan menggunakan uji regresi logistik.

\section{HASIL DAN PEMBAHASAN}

Total siswa di SMP Negeri 238 Jakarta adalah 620 siswa yang terdiri dari 18 kelas. Systematic random sampling dilakukan pada unit kelas, sehingga didapatkan 107 siswa. Karakteristik siswa didominasi berusia 13-15 tahun yaitu sebanyak 86,9\% (Tabel 1). Sebagian besar berjenis kelamin perempuan yaitu sebanyak 64,5\%. Tingkat ekonomi keluarga responden sebagian besar berekonomi rendah atau dibawah Upah Minimum Regional (UMR) sebanyak 81,3\% dan responden sebagian besar memiliki status gizi yang normal yaitu sebanyak 96,3\%.

Rata-rata konsumsi serat responden adalah 2,79 gram per hari yang dihitung berdasarkan hasil recall 24 hour sedangkan rata-rata konsumsi serat jika dilihat berdasarkan konsumsi sayur dan buah pada hasil SQ-FFQ adalah 2,6 gram perhari, tidak ada perbedaan yang berarti dalam hasil tersebut, dapat dikatakan bahwa ratarata konsumsi serat responden masih sangat rendah dari jumlah yang telah dianjurkan. Hasil ini sangat rendah jika dibandingkan dengan rekomendasi dari AKG 2018 konsumsi serat yang dianjurkan untuk remaja berusia $10-18$ tahun adalah $30-35$ gram per hari.

Tabel 1. Distribusi Frekuensi Karakteristik Responden

\begin{tabular}{lcc}
\hline \multicolumn{1}{c}{ Karakteristik Responden } & Jumlah $(\mathbf{n = 1 0 7})$ & Persentase (\%) \\
\hline Umur & 14 & 13,1 \\
10-12 Tahun & 93 & 86,9 \\
13-15 Tahun & & \\
Jenis Kelamin & 38 & 35,5 \\
$\quad$ Laki-laki & 69 & 64,5 \\
$\quad$ Perempuan & & \\
Tingkat Ekonomi Orang Tua & 87 & 81,3 \\
$\quad$ <UMR & 20 & 18,7 \\
>UMR & 1 & 0,9 \\
Status Gizi & 103 & 96,3 \\
Kurus & 3 & 2,8 \\
Normal & & \\
Gemuk & & \\
\hline
\end{tabular}

Konsumsi sayur dan buah yang baik ( $\geq 5$ porsi per hari) dalam penelitian ini terdapat $24,3 \%$ responden yang dihitung berdasarkan hasil SQ-FFQ (Tabel 2). 
Farida (2007) menyebutkan bahwa terdapat $5,5 \%$ remaja di Indonesia yang mengkonsumsi sayur dan buah $\geq 5$ porsi per hari. Wiramah (2016) melaporkan bahwa di SMA Negeri 97 Jakarta hanya terdapat 2,7 $\%$ remaja yang mengkonsumsi sayur dan buah per hari, lebih dari rekomendasi. Dengan demikian dapat disimpulkan bahwa hasil konsumsi sayur dan buah remaja pada penelitian ini cukup baik dibandingkan penelitian sebelumnya di Jakarta, meskipun masih kurang dari anjuran WHO (2018).

Tabel 2. Frekuensi Konsumsi Sayur Buah, Tingkat Pengetahuan, Self-Efficacy, Ketersediaan Sayur, dan Buah, Serta Pengaruh Orang Tua

\begin{tabular}{|c|c|c|}
\hline Variabel & Jumlah (n=107) & Persentase (\%) \\
\hline \multicolumn{3}{|l|}{ Konsumsi Sayur } \\
\hline Kurang & 98 & 91,6 \\
\hline Baik & 9 & 8,4 \\
\hline \multicolumn{3}{|l|}{ Konsumsi Buah } \\
\hline Kurang & 74 & 69,2 \\
\hline Baik & 33 & 30,8 \\
\hline \multicolumn{3}{|l|}{ Konsumsi Sayur \& Buah } \\
\hline Kurang & 81 & 75,7 \\
\hline Baik & 26 & 24,3 \\
\hline \multicolumn{3}{|l|}{ Tingkat Pengetahuan } \\
\hline Kurang & 45 & 42,1 \\
\hline Baik & 62 & 57,9 \\
\hline \multicolumn{3}{|l|}{ Self Efficacy } \\
\hline Kurang & 68 & 63,6 \\
\hline Baik & 39 & 36,4 \\
\hline \multicolumn{3}{|c|}{ Ketersediaan Sayur dan Buah } \\
\hline Kurang & 44 & 41,1 \\
\hline Baik & 63 & 58,9 \\
\hline \multicolumn{3}{|l|}{ Pengaruh Orang Tua } \\
\hline Kurang & 44 & 41,1 \\
\hline Baik & 63 & 58,9 \\
\hline
\end{tabular}

Sebagian besar responden memilki pengetahuan baik $(57,9 \%)$, dan memiliki Self Efficacy yang kurang $(63,6 \%)$ dan ketersediaan sayur dan buah, serta pengaruh orang tua yang baik $(58,9 \%)$. Self efficacy adalah keyakinan yang seseorang miliki pada kemampuan di diri sendiri (Flammer, 2001). Self efficacy berperan banyak dalam mekanisme yang menyediakan perubahan pola makan, khususnya pada konsumsi buah dan sayur. Self efficacy menyediakan pencapaian tujuan dikarenakan menjadi langkah awal dalam perencanaan dan perilaku individu (Anggraeni, 2018). 
Tabel 3. Distribusi Responden dalam memenuhi Ketersediaan Sayur dan Buah

\begin{tabular}{lcc}
\hline & Jumlah (n=107) & \% \\
\hline Membeli kebutuhan Sayur dan Buah & & \\
\hline Pasar & 73 & 68,2 \\
Supermarket & 20 & 18,7 \\
Toko Buah/Sayur & 14 & 13,1 \\
\hline Jarak untuk membeli kebutuhan Sayur dan Buah & & \\
\hline Dekat & 42 & 39,3 \\
Jauh, tetapi dapat ditempuh dengan berjalan kaki & 42 & 39,3 \\
Jauh, tidak dapat ditempuh dengan berjalan kaki & 23 & 21,1 \\
\hline
\end{tabular}

Ketersediaan makanan dapat Dalam memenuhi ketersediaan sayur dan mempengaruhi pola konsumsi terhadap buah, siswa sebagian besar membeli sayur pemilihan makanan, jika ketersediaan pada dan buah di pasar yaitu sebanyak $68,2 \%$ makanan rendah maka kemampuan dengan rata-rata jarak responden untuk individu dalam mengkonsumsi makanan membeli sayur dan buah dapat ditempuh akan menjadi terasa sulit (Rachman, 2017). dengan berjalan kaki $(39,3 \%)$.

Tabel 4. Distribusi Responden Berdasarkan Frekuensi Konsumsi Sayur \& Buah

\begin{tabular}{lc}
\hline \multicolumn{1}{c}{ Bahan Makanan } & Frekuensi per minggu \\
\hline Sayur & \\
Wortel & 0.82 \\
Bayam & 0,61 \\
Kangkung & 0,59 \\
Buncis & 0,40 \\
Sawi Hijau & 0,37 \\
\hline Buah & \\
Jeruk & 0,91 \\
Mangga & 0,81 \\
Melon & 0,31 \\
Semangka & 0,30 \\
Jambu Biji & 0,26 \\
\hline
\end{tabular}

Hasil distribusi frekuensi konsumsi per minggu, wortel merupakan jenis sayur dengan frekuensi konsumsi sayur tertinggi yaitu sebanyak 0,82 kali, sedangkan jeruk merupakan jenis buah dengan frekuensi konsumsi buah tertinggi yaitu sebanyak 0,91 kali. Hasil yang kurang dari 1 dikarenakan asupan responden yang masih kurang. Berdasarkan hasil statistik menunjukkan bahwa tidak ada hubungan yang signifikan antara tingkat pengetahuan terhadap konsumsi sayur dan buah pada remaja ( $p=0,063$ ) (Tabel 3). Responden yang memiliki tingkat pengetahuan baik sebagian besar mengkonsumsi sayur dan buah kurang, yaitu 63,0\% dibandingkan yang memiliki tingkat pengetahuan dan konsumsi sayur dan buahnya baik yaitu 
42,3\%. Kemungkinan responden dalam konsumsi sayur dan buah baik pada tingkat baik. Temuan ini tidak sejalan dengan hasil penelitian Lestari (2012) yang menunjukkan adanya hubungan signifikan pengetahuan kurang adalah 1,8 kali dibandingkan dengan tingkat pengetahuan antara pengetahuan dengan konsumsi sayur dan buah.

Tabel 5. Hasil Analisis antara Variabel Independen dengan Variabel Dependen

\begin{tabular}{|c|c|c|c|c|c|c|c|c|}
\hline & \multicolumn{4}{|c|}{ Konsumsi Sayur \& Buah } & \multirow{2}{*}{\multicolumn{2}{|c|}{ Total }} & \multirow{3}{*}{$\begin{array}{c}p \\
\text { value }\end{array}$} & \multirow{3}{*}{$\begin{array}{c}\mathrm{RR} \\
(95 \% \mathrm{CI})\end{array}$} \\
\hline & \multicolumn{2}{|c|}{ Baik } & \multicolumn{2}{|c|}{ Kurang } & & & & \\
\hline & $\mathrm{N}$ & $\%$ & $\mathrm{~N}$ & $\%$ & $\mathrm{~N}$ & $\%$ & & \\
\hline \multicolumn{9}{|l|}{ Tingkat } \\
\hline \multicolumn{9}{|l|}{ Pengetahuan } \\
\hline Baik & 11 & 42,3 & 51 & 63,0 & 62 & 57,9 & \multirow{2}{*}{0,063} & 0,532 \\
\hline Kurang & 15 & 57,7 & 30 & 37,0 & 45 & 42,1 & & $(0,271-1,047)$ \\
\hline \multicolumn{9}{|l|}{ Self Efficacy } \\
\hline Baik & 14 & 53,8 & 25 & 30,9 & 39 & 36,4 & & 2,034 \\
\hline Kurang & 12 & 46,2 & 56 & 69,1 & 68 & 63,6 & 0,034 & $(1,048-3,947)$ \\
\hline \multicolumn{9}{|c|}{ Ketersediaan } \\
\hline \multicolumn{9}{|c|}{ Sayur dan Buah } \\
\hline Baik & 11 & 42,3 & 52 & 64,2 & 63 & 58,9 & & 0,512 \\
\hline Kurang & 15 & 57,7 & 29 & 35,8 & 44 & 41,1 & 0,048 & $(0,261-1,007)$ \\
\hline \multicolumn{9}{|c|}{ Pengaruh Orang } \\
\hline \multicolumn{9}{|l|}{ Tua } \\
\hline Baik & 20 & 76,9 & 43 & 53,1 & 63 & 58,9 & & 2,328 \\
\hline Kurang & 6 & 23,1 & 38 & 46,9 & 44 & 41,1 & 0,032 & $(1,018-5,323)$ \\
\hline
\end{tabular}

Dalam penelitiannya siswa yang memiliki pengetahuan baik cenderung untuk mengkonsumsi buah dansayur dengan cukup dibandingkan yang memiliki pengetahuan kurang. Namun demikian, temuan ini sejalan dengan yang dilaporkan Ramadhani (2017) bahwa tidak ada hubungan yang signifikan antara pengetahuan dengan konsumsi sayur dan buah, remaja putri yang memiliki kategori pengetahuan rendah, rata-rata mengkonsumsi sayur dan buah yang lebih besar dibandingkan dengan yang memiliki kategori pengetahuan baik. Hal tersebut menunjukkan bahwa pengetahuan gizi yang baik, belum tentu menghasilkan dampak semakin baiknya konsumsi sayur dan buah pada siswa (Krolner et al., 2011). Oleh karena itu siswa yang memiliki pengetahuan baik, belum tentu dapat memahami atau mengaplikasikannya dengan baik.

Hasil statistik menunjukkan bahwa ada hubungan yang signifikan diantara self efficacy dengan konsumsi sayur dan buah remaja $(\mathrm{p}=0,034)$. Responden yang memiliki self efficacy baik dan konsumsi sayur dan buah baik terdapat 53,8\%, sedangkan yang memiliki self efficacy kurang dan konsumsi sayur dan buah baik 
terdapat $46,2 \%$. Responden yang memiliki self efficacy baik memiliki peluang untuk konsumsi sayur dan buah baik dua kali lebih besar dibandingkan dengan responden yang memiliki self efficacy kurang.

Hasil ini sejalan dengan hasil penelitian Wiramah (2016) yang menunjukkan adanya hubungan signifikan antara self efficacy dengan konsumsi sayur dan buah. Sebagian besar remaja dengan asupan sayur dan buahnya kurang, lebih banyak memiliki keyakinan untuk konsumsi sayur dan buah setiap hari, dengan porsi empat kali lipat lebih besar bagi remaja untuk memiliki self efficacy positif.

Keyakinan responden dapat mengkonsumsi buah setiap hari dan mengkonsumsi sayur sesuai porsi setiap hari merupakan hal yang dapat mempengaruhi asupan konsumsi sayur dan buah. Keyakinan dalam mengkonsumsi sayur dan buah adalah faktor yang paling sesuai dan berpengaruh untuk meningkatkan konsumsi dan memberikan kemungkinan yang positif dalam tahap perubahan (Van Duyn et al., 2001).

Hasil uji statistik menunjukkan ada hubungan antara ketersediaan sayur dan buah dengan konsumsi sayur dan buah ( $\mathrm{p}=$ 0,048). Responden yang di rumah memiliki ketersedian sayur dan buah kurang dan mengkonsumsi sayur dan buah baik sebanyak $57,7 \%$ dan yang memiliki ketersediaan sayur dan buah baik dan mengkonsumsi sayur dan buah baik sebanyak 42,3\%. Kemungkinan responden dalam konsumsi sayur dan buah baik pada ketersediaan sayur dan buah kurang adalah 1,9 kali (1/0,512) dibandingkan dengan ketersediaan sayur dan buah baik.

Pada hasil penelitian Rachman (2017) bahwa ada hubungan yang signifikan antara ketersediaan sayur dan buah dengan konsumsi sayur dan buah. Hubungannya positif, yaitu semakin tinggi ketersediaan sayur dan buah, maka semakin tinggi pula konsumsi sayur dan buah setiap individu.

Namun pada penelitian ini responden yang memiliki ketersediaan baik cenderung mengkonsumsi sayur dan buah kurang, hal tersebut dikarenakan sebagian responden pada penelitian ini memiliki keyakinan diri untuk mengkonsumsi sayur dan buah yang rendah. Sebagian besar anak memiliki pemahaman yang baik terhadap sayur dan buah tetapi perilaku anak dalam mengkonsumsi sayur dan buah masih sangat rendah, dikarenakan kurangnya gambaran bagi anak untuk makan sayur dan buah setiap hari (Dewi, 2013).

Hasil penelitian ini menunjukkan sebagian besar responden membeli sayur dan buah di pasar yang dapat ditempuh dengan berjalan kaki. Namun sebagian 
besar responden jarang ( $<1-3 \mathrm{kali} /$ minggu) memenuhi ketersediaan sayur dan buah di rumah setiap hari.

Hasil statistik pada penelitian ini menunjukkan ada hubungan yang signifikan antara pengaruh orangtua dengan konsumsi sayur dan buah $(\mathrm{p}=0,032)$. Responden yang memiliki pengaruh orangtua dan konsumsi sayur dan buah baik sebanyak 76,9\% dan yang memiliki pengaruh orangtua kurang dengan konsumsi sayur dan buah baik sebanyak $23,1 \%$. Responden yang memiliki pengaruh orang tua baik memiliki peluang untuk konsumsi sayur dan buah baik dua kali lebih besar dibandingkan dengan responden yang memiliki pengaruh orang tua kurang.

\section{Kesimpulan dan Saran}

Terdapat hubungan yang siginifikan antara konsumsi sayur dan buah dengan self efficacy, ketersediaan sayur dan buah, dan pengaruh orangtua pada remaja SMP Negeri 238 Jakarta. Tidak terdapat hubungan yang signifikan terhadap konsumsi sayur dan buah dengan tingkat pengetahuan pada remaja SMP Negeri 238 Jakarta.

Diharapkan bagi sekolah dapat melakukan gerakan makan sayur dan buah setiap hari yang dilakukan bekerja sama dengan penjual makanan di kantin untuk menyediakan makanan yang mengandung
Hasil penelitian ini sejalan dengan temuan Lestari (2012) yang menunjukkan ada hubungan yang signifikan antara kebiasaan orangtua dengan perilaku konsumsi sayur dan buah. Dalam penelitiannya, remaja yang memiliki kebiasaan orang tua kurang, maka konsumsi buah dan sayur juga kurang.

Pengaruh orangtua yang sering mengingatkan dan mengajak anak untuk selalu konsumsi sayur dan buah setiap hari dapat meningkatkan ketertarikan atau daya keinginan anak untuk selalu mengkonsumsi sayur dan buah (De Bourdeaudhuij et al., 2008).

sayur dan menjual buah potong agar siswa dapat tertarik untuk konsumsi sayur dan buah setiap hari. Melakukan penyuluhan atau pendidikan gizi yang bekerja sama dengan Dinas Kesehatan atau mahasiswa gizi untuk meningkatkan pengetahuan siswa.

Bagi orangtua diharapkan dapat meyakinkan dan memberikan dukungan dalam mengkonsumsi sayur dan buah, dan dapat terus meningkatkan ketersediaan sayuran dan buah di rumah. Diharapkan bagi peneliti lain, dapat meneliti faktorfaktor lain yang dapat mempengaruhi asupan konsumsi sayur dan buah yang 
belum ada di penelitian ini serta menggunakan metode lain seperti food record yang dilakukan selama satu minggu

\section{DAFTAR PUSTAKA}

Anggraeni, NA. 2018. Faktor Dominan Konsumsi Buah dan Sayur pada Remaja di SMP NEGERI 98 Jakarta. Indonesian Journal of Human Nutrition. Vol. 5, No. 1.

Arikunto, S. 2006. Prosedur penelitian suatu pendekatan praktik. Rineka Cipta. Jakarta.

Aswatini NM., Fitranita. 2008. Konsumsi Sayur Dan Buah Di Masyarakat Dalam Konteks Pemenuhan Gizi Seimbang. Jurnal Kependudukan Indonesia. Vol III. No 02.

Balitbang Kemenkes Republik Indonesia. 2013. Riset Kesehatan Dasar Dalam Angka Provinsi DKI Jakarta 2013. Badan Penelitian dan Pengembangan Kesehatan. Jakarta.

Balitbang Kemenkes Republik Indonesia. 2018. Laporan Nasional Riset Kesehatan Dasar 2018. Badan Penelitian dan Pengembangan Kesehatan. Jakarta.

De Bourdeaudhuij I., te Velde S., Brug J., Due P., Wind M., Sandvik C., Maes L., Wolf A., Perez Rodrigo C., Yngve A., Thorsdottir I., Rasmussen M., Elmadfa I., Franchini B., Klepp KI. 2007. Personal, Social And Environmental Predictors Of Daily Fruit And Vegetable Intake In 11Year-Old Children In Nine European Countries. European Journal of Clinical Nutrition. 62(7):834-4.

Dewi Y. 2013. Sudi Deskriptif: Persepsi dan Perilaku Makan Buah dan Sayuran pada Anak Obesitas dan Orang Tua. Jurnal Ilmiah Mahasiswa Universitas Surabaya. Vol. 2 No. 1.

Farida I. 2010. Faktor-Faktor Yang Berhubungan Dengan Perilaku Konsumsi Sayur dan Buah Pada untuk menghitung konsumsi sayur dan buah.

Remaja Di Indonesia Tahun 2007. [Skripsi] Fakultas Kedokteran dan Ilmu Kesehatan UIN: Jakarta.

Farisa, S. 2012. Hubungan Sikap, Pengetahuan, Ketersediaan dan Keterpaparan Media Massa dengan Konsumsi Buah dan Sayur Pada Siswa SMPN 8 Depok Tahun 2012. [Skripsi] Fakultas Kesehatan Masyarakat UI: Depok.

Kementrian Kesehatan RI. 2016. Inilah Perbedaan '4 Sehat 5 Sempurna' Dengan 'Gizi Seimbang'. http://www.depkes.go.id/article/view /16051300001/inilah-perbedaan-4sehat-5-sempurna-dengan-giziseimbang-.html (diakses 18 September 2019).

Kementrian Kesehatan RI. 2017. Hari Gizi Nasional 2017: Ayo Makan Sayur dan Buah Setiap Hari. http://www.depkes.go.id/article/view /17012600002/hari-gizi-nasional2017-ayo-makan-sayur-dan-buahsetiap-hari.html (diakses 4 September 2019)

Krolner R., Rasmussen M., Brug J., Klepp Kl., Wind M., Due P. 2011. Determinants of fruit and vegetable consumption among children and adolescents: a review of theliterature. Part II: qualitative studies. International Journal Of Behavioral Nutrition and Physical Activity 8:112. Lestari AD. 2012. Faktor-Faktor Yang Berhubungan Dengan Perilaku Konsumsi Sayur dan Buah Pada Siswa Smp 226 Jaksel Tahun 2012. [Skripsi] Fakultas Kedokteran dan Ilmu Kesehatan UIN: Jakarta.

Notoatmodjo, S. 2010. Metodologi Penelitian Kesehatan. Jakarta : PT RINEKA CIPTA.

Pardede, E. 2013. Tinjauan Komposisi Kimia Buah Dan Sayur: Peranan 
Sebagai Nutrisi Dan Kaitannya Dengan Teknologi Pengawetan Dan Pengolahan. Jurnal VISI. Vol 21. No.3. ISSN 0853 - 0203: 2013.

Rachman BN., Mustika IG., Kusumawati IGAW. 2017. Faktor yang berhubungan dengan perilaku konsumsi buah dan sayur siswa SMP di Denpasar. Jurnal Gizi Indonesia (The Indonesian Journal of Nutrition). 6 (1), 2017 e-ISSN : 23383119, p-ISSN: 1858-4942.

Ramadhani DT., Hidayati L. 2017. FaktorFaktor Yang Mempengaruhi Konsumsi Sayur Dan Buah Pada Remaja Putri SMP Negeri 3 Surakarta. Seminar Nasional Gizi 2017 Program Studi Ilmu Gizi UMS "Strategi Optimasi Tumbuh Kembang Anak”. ISSN: 2579-9622.

Van Duyn MA., Kristal AR., Dodd K., Campbell MK., Subar AF., Stables G., Nebeling L., Glanz K. 2001. Association of awareness, intrapersonal and interpersonal factors, and stage of dietary change with fruit and vegetable consumption: a national survey. American Journal of Health Promotion. 16 (2): 69-78.

World Health Organization. 2018. Global Strategy on Diet, Physical Activity and Health : Promoting fruit and vegetable consumption around the world.

https://www.who.int/dietphysicalacti vity/fruit/en/ (diakses 11 September 2019).

Wirakusumah, E.S. 2007. Jus Buah dan Sayuran. Penebar Swadaya. Jakarta.

Wiramah, N. 2016. Faktor-Faktor Yang Berhubungan Dengan Konsumsi Buah dan Sayur Pada Siswa SMA Negeri 97 Jakarta Tahun 2016. [Skripsi] Fakultas Kesehatan Masyarakat UI: Depok.

Young EM., Fors SW., Hayes DM. 2004. Associations between perceived parent behaviors and middle school student fruit and vegetable consumption. Journal of Nutrition Education and Behavior. 36: 2-8. 